\title{
Front Matter: Volume 9506
}

, "Front Matter: Volume 9506," Proc. SPIE 9506, Optical Sensors 2015, 950601 (19 May 2015); doi: 10.1117/12.2197870

SPIE. Event: SPIE Optics + Optoelectronics, 2015, Prague, Czech Republic 


\title{
PROCEEDINGS OF SPIE
}

\section{Optical Sensors 2015}

\author{
Francesco Baldini \\ Jiri Homola \\ Robert A. Lieberman \\ Editors
}

13-16 April 2015

Prague, Czech Republic

Sponsored by

SPIE

Cooperating Organisations

HiPER Project (United Kingdom)

ELI Beamlines (Czech Republic)

Laserlab Europe

Published by

SPIE 
The papers included in this volume were part of the technical conference cited on the cover and title page. Papers were selected and subject to review by the editors and conference program committee. Some conference presentations may not be available for publication. The papers published in these proceedings reflect the work and thoughts of the authors and are published herein as submitted. The publisher is not responsible for the validity of the information or for any outcomes resulting from reliance thereon.

Please use the following format to cite material from this book:

Author(s), "Title of Paper," in Optical Sensors 2015, edited by Francesco Baldini, Jiri Homola,

Robert A. Lieberman, Proceedings of SPIE Vol. 9506 (SPIE, Bellingham, WA, 2015) Article CID Number.

ISSN: 0277-786X

ISBN: 9781628416275

Published by

SPIE

P.O. Box 10, Bellingham, Washington 98227-0010 USA

Telephone +1 3606763290 (Pacific Time) · Fax +1 3606471445

SPIE.org

Copyright (@ 2015, Society of Photo-Optical Instrumentation Engineers.

Copying of material in this book for internal or personal use, or for the internal or personal use of specific clients, beyond the fair use provisions granted by the U.S. Copyright Law is authorized by SPIE subject to payment of copying fees. The Transactional Reporting Service base fee for this volume is $\$ 18.00$ per article (or portion thereof), which should be paid directly to the Copyright Clearance Center (CCC), 222 Rosewood Drive, Danvers, MA 01923. Payment may also be made electronically through CCC Online at copyright.com. Other copying for republication, resale, advertising or promotion, or any form of systematic or multiple reproduction of any material in this book is prohibited except with permission in writing from the publisher. The CCC fee code is 0277-786X/15/\$18.00.

Printed in the United States of America.

Publication of record for individual papers is online in the SPIE Digital Library.

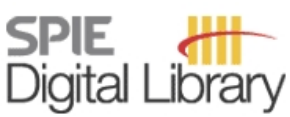

SPIEDigitalLibrary.org

Paper Numbering: Proceedings of SPIE follow an e-First publication model, with papers published first online and then in print. Papers are published as they are submitted and meet publication criteria. A unique citation identifier (CID) number is assigned to each article at the time of the first publication. Utilization of CIDs allows articles to be fully citable as soon as they are published online, and connects the same identifier to all online, print, and electronic versions of the publication. SPIE uses a six-digit CID article numbering system in which:

- The first four digits correspond to the SPIE volume number.

- The last two digits indicate publication order within the volume using a Base 36 numbering

system employing both numerals and letters. These two-number sets start with 00, 01, 02, 03, 04, $05,06,07,08,09,0 A, 0 B \ldots$ OZ, followed by 10-1Z, 20-2Z, etc.

The CID Number appears on each page of the manuscript. The complete citation is used on the first page, and an abbreviated version on subsequent pages. 


\title{
Contents
}

\author{
vii Authors \\ xi Conference Committee
}

SESSION 1 COMPONENTS, SUBSYSTEMS, DATA PROCESSING I

950603 Modeling of CMOS image sensors for time-of-flight applications [9506-3]

950604 Radiometric calibration of digital cameras using Gaussian processes [9506-4]

950605 Hyperspectral light field imaging [9506-5]

\section{SESSION 2 COMPONENTS, SUBSYSTEMS, DATA PROCESSING II}

950606 Ф-OTDR signal amplification [9506-6]

950607 Real time polarization sensor image processing on an embedded FPGA/multi-core DSP system [9506-7]

950608 Integrated optics on lithium niobate for sensing applications [9506-8]

\section{SESSION 3 PHYSICAL SENSORS I}

9506 0A A suite of optical fibre sensors for structural condition monitoring (Invited Paper) [9506-12]

9506 OB Photoluminescent temperature sensor based on borate and phosphate glasses doped with copper clusters [9506-13]

9506 OC FBG-based novel sensor for high-temperature measurement and its low-cost interrogation [9506-14]

9506 OD Polarimetric and fiber Bragg grating reflective hybrid sensor for simultaneous measurement of strain and temperature in composite material [9506-15]

\section{SESSION 4 PHYSICAL SENSORS II}

9506 OF Compact optical displacement sensing by detection of microwave signals generated from a monolithic passively mode-locked laser under feedback [9506-17]

9506 OG A compact semiconductor digital interferometer and its applications [9506-18]

$9506 \mathrm{OH}$ Effective application of optical sensing technology for sustainable liquid level sensing and rainfall measurement [9506-20] 
9506 Ol Microstructure encryption and decryption techniques in optical variable and invariable devices in printed documents for security and forensic applications [9506-21]

\section{SESSION 5 MATERIALS AND FUNCTIONALIZATIONS}

$95060 \mathrm{~J}$ Advanced materials for improving biosensing performances of propagating and localized plasmonic transducers (Invited Paper) [9506-22]

\section{SESSION $6 \quad$ PLASMONIC SENSING I}

9506 ON Plasmonically amplified fluorescence bioassay with microarray format (Invited Paper) [9506-26]

950600 Morphological studies of resonances in plasmonic metasurfaces for SPR sensing [9506-27]

9506 OR The development of multi incident angles and multi points measurement phase image interrogation surface plasmon resonance system [9506-30]

\section{SESSION $7 \quad$ PLASMONIC SENSING II}

9506 OS Nano slot-antenna array refractive index sensors: approaching the conventional theoretical limit of the figure of merit [9506-31]

9506 OU Ultrasensitive graphene coated SPR sensor for biosensing applications [9506-33]

9506 OV Biosensing platform combining label-free and labelled analysis using Bloch surface waves [9506-34]

9506 OW Quantitative detection of bovine and porcine gelatin difference using surface plasmon resonance based biosensor [9506-35]

\section{SESSION 8 RAMAN SPECTROSCOPY}

$95060 Z$ Discrimination and classification of acute lymphoblastic leukemia cells by Raman spectroscopy [9506-38]

\section{SESSION 9 CHEMICAL SENSORS AND BIOSENSORS I}

950611 Fibre tip pH sensor for tumor detection during surgery [9506-40]

950612 Fiber optic pH sensing system with microscopic spatial resolution [9506-41]

950613 Study of the grafting of dyes for the design of a pH optode [9506-42] 
950614 Localised hydrogen peroxide sensing for reproductive health [9506-43]

950615 Cancer-cells on a chip for label-free optic detection of secreted molecules [9506-44]

950617 Optical micro-bubble resonators as promising biosensors [9506-46]

\section{POSTER SESSION}

9506 1A Monitoring of high refractive index edible oils using coated long period fiber grating sensors [9506-19]

9506 1B A new method to measure low-order aberrations based on wavefront slope [9506-50]

9506 ID Flexible SPR system able to switch between Kretschmann and SPRi [9506-53]

9506 IE PDMS based micro-optics and microchannels for lab-on-a-chip application [9506-55]

9506 IF Development of fast FBG interrogator with wavelength-swept laser [9506-56]

$9506 \mathrm{1H}$ Evaluation of an affinity-amplified immunoassay of graphene oxide using surface plasmon resonance biosensors [9506-58]

950611 Highly birefringent fiber-based temperature sensor utilizing the wavelength interrogation [9506-59]

$95061 \mathrm{~J}$ Fiber Bragg grating sensors as a tool to evaluate the influence of filler on shrinkage of geopolymer matrices [9506-60]

9506 IK FBG based novel sensor design for low vacuum measurement with high sensitivity [9506-61]

$9506 \mathrm{lL}$ Strain measurements of a multilayer panel via Fiber Bragg gratings as novel approach for deflection monitoring of tracking particle detectors [9506-62]

$95061 \mathrm{M}$ Magnetic field measurement using a fiber laser sensor in ring arrangement [9506-63]

9506 IN Quantum noise limit of phase microoptical gyro sensitivity [9506-64]

950610 Automatic recognition system of aquatic organisms by classical and fluorescence microscopy [9506-65]

9506 IP Gold and aluminum based surface plasmon resonance biosensors: sensitivity enhancement [9506-66]

$95061 Q \quad$ Optical sensing of rainbow for non-contact gauging of diameter and refractive index of an axisymmetric transparent fiber [9506-67]

9506 IR Hybrid organic-inorganic semiconductor transducer for optical and electrical sensing [9506-68] 
9506 is Tunable diode laser absorption spectroscopy on $2.05 \mu \mathrm{m}$ for the $\mathrm{CO}_{2}$ concentration measurement [9506-69]

9506 IT A silicon-based peptide biosensor for label-free detection of cancer cells [9506-71]

9506 IU 3D imaging of translucent media with a plenoptic sensor based on phase space optics [9506-72]

9506 IV Experimental results for characterization of a tapered plastic optical fiber sensor based on SPR [9506-73]

9506 IW Magneto-plasmonic response as a perspective tool to magnetic field sensing [9506-74]

$95061 \mathrm{X}$ Graphene-like coatings for biosensors devices [9506-75]

$95061 \mathrm{Z}$ Photoluminescence characterization of ZnO nanowires functionalization [9506-78]

950620 Optical sensors based on the molecular condensation nuclei detector [9506-79]

950621 Research on optical fiber microphone array based on Sagnac interferometer [9506-81]

950623 Determination of plume temperature distribution based on the ratios of the radiation intensities of multiple $\mathrm{CO}_{2}$ lines [9506-83]

950624 Application research in nonuniformity correction algorithm of IRFPA for infrared measuring system [9506-84]

950626 Remote optoelectronic sensors for monitoring of nonlinear surfaces [9506-86]

950627 Method of simultaneous measurement of bending forces and temperature using Bragg gratings [9506-87]

950628 Investigating temperature effects on the spectral lines of blue laser diodes for monitoring $\mathrm{NO}_{2}$ gas pollution [9506-88]

950629 Evolution of blue laser diode spectral lines with applied current in the range $446-448 \mathrm{~nm}$ [9506-89]

$95062 \mathrm{~A}$ Active differential optical absorption spectroscopy for $\mathrm{NO}_{2}$ gas pollution using blue light emitting diodes [9506-90]

9506 2B Volume holographic gratings as optical sensor for heavy metal in bathing waters [9506-91]

9506 2C Cable television monitoring system based on fiber laser and FBG sensor [9506-92]

$95062 \mathrm{H} \quad$ A novel 'gold on gold' biosensing scheme for an on-fiber immunoassay (Best Student Paper Award) [9506-98] 


\title{
Authors
}

Numbers in the index correspond to the last two digits of the six-digit citation identifier (CID) article numbering system used in Proceedings of SPIE. The first four digits reflect the volume number. Base 36 numbering is employed for the last two digits and indicates the order of articles within the volume. Numbers start with 00, 01, 02, 03, 04, 05, 06, 07, 08, 09, OA, OB...0Z, followed by 10-1Z, 20-2Z, etc.

\author{
Abell, Andrew D., 14 \\ Abraha, Kamsul, OW \\ Afzal, Muhammad Hassan Bin, $\mathrm{OH}$ \\ Al-Basheer, Watheq, 28, 29, 2A \\ Aljalal, Abdulaziz, 28, 29, 2A \\ Ambadiyil, Sajan, 01 \\ Andrés, M. V., 1M \\ Anopchenko, Aleksei, OV \\ Apparao, T. V., OC \\ Arcari, Paolo, $1 \mathrm{~T}$ \\ Argiolas, N., 08 \\ Arifin, Muhammad, $O W$ \\ Babkina, Anastasiia N., OB \\ Bacco, D., 1X \\ Balagura, Iryna $\vee$., OG \\ Baldini, F., 17 \\ Baptista, J. M., $1 \mathrm{M}$ \\ Barra, M., IR \\ Barucci, A., 17 \\ Bauch, M., ON \\ Bednara, Marcus, 07 \\ Berneschi, S., 17 \\ Berthuy, Ophélie I., 15 \\ Bettella, G., 08 \\ Bhavsar, K., OU \\ Bianco, G., 2B \\ Bieda, Marcin S., OD \\ Biednov, Mykola, IP \\ Blum, Loïc J., 15 \\ Boag, Amir, OS \\ Borbone, F., 2B \\ Britsky, Oleksander I., OG \\ Calio, A., IR \\ Callen, David F., 11 \\ Campopiano, Stefania, 1 J, 1L \\ Carlton, J., OA \\ Casalino, M., IR \\ Cassinese, A., $1 R$ \\ Cennamo, N., IV \\ Chandrawati, Rona, OV \\ Chiu, Nan-Fu, $1 \mathrm{H}$ \\ Chuchacz-Kowalczyk, Katarzyna, 07 \\ Ciampolillo, M., 08 \\ Cięszczyk, S., 23 \\ Cioffi, Raffaele, $1 \mathrm{~J}$ \\ Ciprian, D., 11 \\ Coelho, Luís, $1 \mathrm{~A}$ \\ Collette, J. L., 10 \\ Colombelli, A., OJ
}

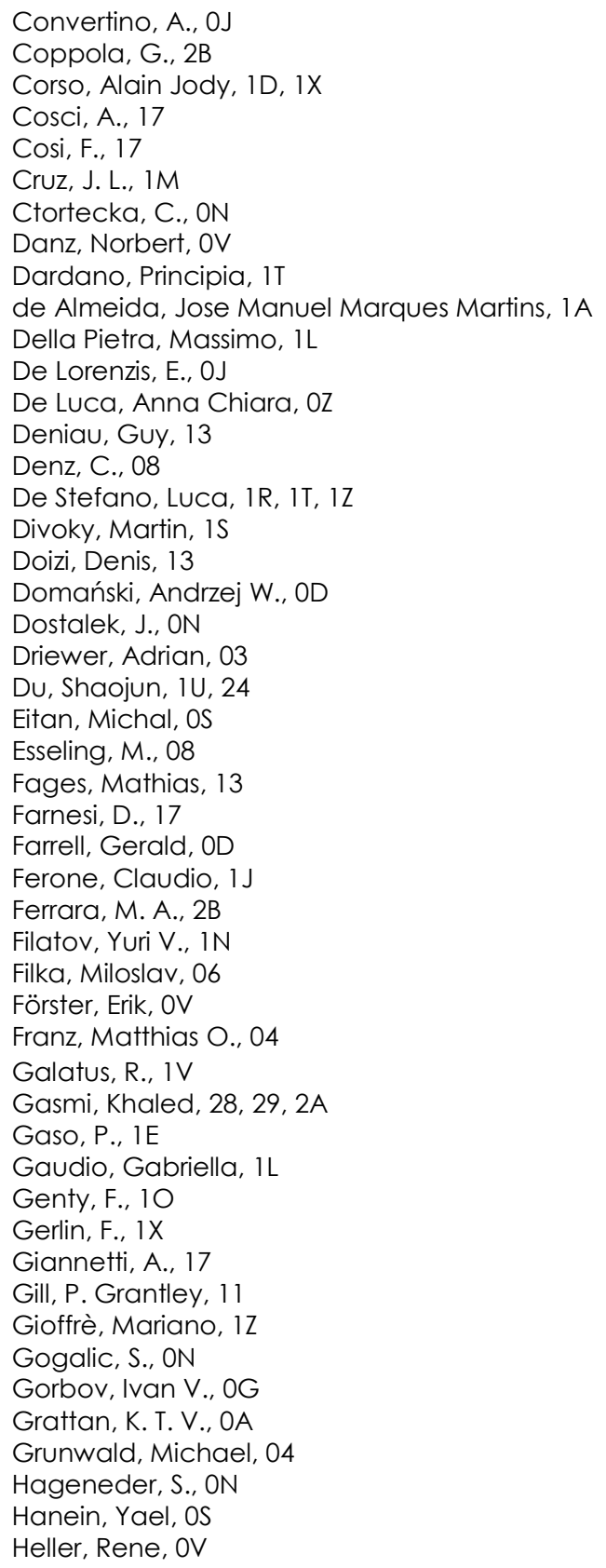


Henderson, Matthew R., 11

Hlubina, P., 11

Homola, Jiří, 00

Horvath, Tomas, 06

Hosticka, Bedrich J., 03

Huang, Jun-Han, 2C

Huang, Teng-Yi, $1 \mathrm{H}$

ladicicco, Agostino, 1J, $1 \mathrm{~L}$

lluz, Zeev, OS

Jandura, D., 1E

Jiang, Zongfu, 1B

Jorge, P. A. S., IM

K. G, Jayan, Ol

Kadulova, M., 11

Kamineni, Srimannarayana, 0C, $1 \mathrm{~K}$

Kašík, Ivan, 12

Katelevsky, Vadim Ya., 20

Kenda, Andreas, 05

Khan, I., ON

Kisała, Piotr, 27

Kolobkova, Elena $\mathrm{V}$., OB

Konyakhin, Igor A., 26

Kroesen, S., 08

Kuczkowski, Michał, OD

Kuo, Chun-Chuan, $1 \mathrm{H}$

Kuptsov, Vladimir D., 20

Kwiecien, Pavel, 00

Lamberti, Annalisa, IT

Lauffer, M., 10

Lebyedyeva, Tetyana, IP

Lee, Shu-Sheng, OR

Leitner, Raimund, 05

Lelek, Jakub, 00

Lesiak, Piotr, OD

Lesňák, M., IW

Liao, Jyun, OR

Lin, Shih-Yuan, OR

Liu, Wenguang, 1B

Madhuvarasu, Sai Shankar, IK

Mahadevan Pillai, V. P., OI

Malitesta, C., OJ

Mamidi, Venkata Reddy, OC, IK

Managò, Stefano, $\mathrm{OZ}$

Manera, M. G., OJ

Margueron, S., 10

Marquette, Christophe A., 15

Martucci, Nicola M., IT

Mascioletti, Alessandro, OV

Messina, Francesco, $1 \mathrm{~J}$

Michelotti, Francesco, OV

Migliaccio, Nunzia, $1 \mathrm{~T}$

Militky, J., 11

Mirabelli, Peppino, $0 Z$

Mocek, Tomas, is

Monro, Tanya M., 11, 14

Mrázek, Jan, 12

Mukherij, S., $2 \mathrm{H}$

Munster, Petr, 06

Munzert, Peter, OV
Nardello, M., $1 \mathrm{X}$

Nascimento, I. M., 1M

Nikas, Thomas, OF

Nikonorov, Nikolay $\mathrm{V}$., OB

Novotny, Vit, 06

Nunzi Conti, G., 17

Otipka, P., IW

Pachava, Vengal Rao, OC, $1 \mathrm{~K}$

Pardelova, M., $1 \mathrm{E}$

Pelizzo, Maria G., 1D, 1X

Pelli, S., 17

Peng, Peng-Chun, 2C

Petrochenko, Andrew V., 26

Petrov, Viacheslav V., OG

Pihan, J. C., 10

Podrazký, Ondřej, 12

Politi, Jane, IR, IZ

Pollard, P., OU

Pozza, G., 08

Prabhu, Radhakrishna, Ol, ou

Pranovich, Alina, 1S

Preininger, Claudia, ON

Proboštová, Jana, 12

Prochazka, Ivan, is

Pudiš, D., $1 \mathrm{E}$

Punjabi, N., 2H

Purdey, Malcolm S., 14

Rana, Subinoy, OV

Rea, llaria, 1T, $1 \mathrm{Z}$

Rella, R., OJ

Rella, S., OJ

Rendina, IVo, 1T, $1 \mathrm{Z}$

Richter, Ivan, 00

Righini, G. C., 17

Ritter, Lesley J., 14

Rizzo, Riccardo, OV

Roviello, A., 2B

Ruggiero, Immacolata, $1 T$

Sada, C., 08

Sai Prasad, R. L. N., OC

Santos, José Luís, 1 A

Satija, J., 2H

Saver, U., ON

Schall, Martin, 04

Schartner, Erik P., 11, 14

Schever, Jacob, OS

Schmieder, Stefan, OV

Schubert, Thomas, OV

Shalymov, Egor V., IN

Shen, Po-Tso, 2C

Shinoda, Yukitaka, $1 \mathrm{~F}$

Shirshnev, Pavel S., OB

Shpylovyy, Pavlo, $1 \mathrm{P}$

Shu, Baihong, 1U, 24

Sidorov, Alexander I., OB

Sifta, Radim, 06

Sima, Stanislav, 06

Simos, Christos, OF 
Simos, Hercules, OF

Sinibaldi, Alberto, OV

Sobota, J., IW

Sonntag, Frank, OV

Soria, S., 17

Spickermann, Andreas, 03

Stevens, Molly M., OV

Striano, V., 2B

Suharyadi, Edi, OW

Sun, T., OA

Sutton-McDowall, Melanie L., 14

Świrniak, Grzegorz, 1Q

Sysel, Petr, 06

Syvridis, Dimitris, OF

Szelag, Mateusz, OD

Taurino, A., OJ

Terracciano, Monica, $1 T$

Tessarolo, E., IX

Thompson, Jeremy G., 14

Tombelli, S., 17

Tortschanoff, Andreas, 05

Trono, C., 17

Umlauf, Georg, 04

Valente, Carmen, $0 z$

Valyukhov, Vladimir P., 20

Venediktov, Vladimir YU., IN

Viegas, Diana, $1 \mathrm{~A}$

Vlček, J., IW

Vogt, Holger, 03

Vojtech, Josef, 06

Vyłykáčová, Soňa, 12

Wang, Jian, 21

Wardani, Devy Pramudyah, OW

Woliński, Tomasz R., OD

Wu, Hongyan, 21

Wu, Shin-Shian, 2C

Yamaguchi, Tatsuya, 1F

Yang, Wei-Yuan, 2C

Yang, $Y i, 24$

Yifat, Yuval, OS

Zaltron, A., 08

Zamboni, R., 08

Zeni, L., IV

Zhang, Chengdong, 24

Zhang, Xuanzhe, $1 \mathrm{U}$

Zhou, Qiong, 1B

Zuccon, Sara, 1D, 1X

Zuppardi, F., 2B

Zuppella, Paola, 1D, 1X

Proc. of SPIE Vol. $9506950601-9$ 


\title{
Conference Committee
}

\author{
Symposium Chairs
}

Jiri Homola, Institute of Photonics and Electronics of the ASCR, v.v.i. (Czech Republic)

Chris Edwards, Central Laser Facility, Science and Technology

Facilities Council (United Kingdom)

Mike Dunne, SLAC National Accelerator Laboratory (United States) and Linac Coherent Light Source (United States)

Ivo Rendina, Istituto per la Microelettronica e Microsistemi, CNR (Italy)

Honorary Symposium Chair

Miroslav Miller, Institute of Photonics and Electronics of the ASCR, v.v.i. (Czech Republic)

Conference Chairs

Francesco Baldini, Istituto di Fisica Applicata Nello Carrara, CNR (Italy)

Jiri Homola, Institute of Photonics and Electronics of the ASCR, v.v.i. (Czech Republic)

Robert A. Lieberman, Lumoptix, LLC (United States)

\section{Conference Programme Committee}

Loïc J. Blum, Université Claude Bernard Lyon 1 (France)

Eduard Brynda, Institute of Macromolecular Chemistry of the ASCR, v.v.i. (Czech Republic)

Artur Dybko, Warsaw University of Technology (Poland)

Günter G. Gauglitz, Eberhard Karls Universität Tübingen (Germany)

Bo Liedberg, Linköping University (Sweden)

Aleksandra Lobnik, University of Maribor (Slovenia)

Ramaier Narayanaswamy, The University of Manchester (United Kingdom)

Claudia Preininger, AIT Austrian Institute of Technology GmbH (Austria)

Reinhardt Willsch, Institut für Photonische Technologien e.V. (Germany) 
Session Chairs

1 Components, Subsystems, Data Processing I

Jiri Homola, Institute of Photonics and Electronics of the ASCR, v.v.i. (Czech Republic)

2 Components, Subsystems, Data Processing II

Robert A. Lieberman, Lumoptix, LLC (United States)

3 Physical Sensors I

Francesco Baldini, Istituto di Fisica Applicata Nello Carrara, CNR (Italy)

4 Physical Sensors II

Tong Sun, City University London (United Kingdom)

5 Materials and Functionalizations

Jakub Dostálek, AIT Austrian Institute of Technology GmbH (Austria)

6 Plasmonic Sensing I

Jiri Homola, Institute of Photonics and Electronics of the ASCR, v.v.i. (Czech Republic)

7 Plasmonic Sensing II

Jiri Homola, Institute of Photonics and Electronics of the ASCR, v.v.i. (Czech Republic)

8 Raman Spectroscopy

Eduard Brynda, Institute of Macromolecular Chemistry of the ASCR, v.v.i. (Czech Republic)

9 Chemical Sensors and Biosensors I

Juergen Popp, Leibniz-Institut für Photonische Technologien e.V. (Germany)

10 Chemical Sensors and Biosensors II

Ivan Kašík, Institute of Photonics and Electronics of the ASCR, v.v.i. (Czech Republic) 